\title{
PENGARUH TINGKAT PENGETAHUAN TERHADAP KEJADIAN KOMPLIKASI DM DI RS PELAMONIA
} MAKASSAR

\author{
The Influence Of Knowledge Levels On The Events Of Diabetes Mellitus Complications In Pelamonia Hospital Of \\ Makassar \\ Sukriyadi, Suhartatik, Abdul Hady, Budi Setyawan Ekacipto \\ Poltekkes Kemenkes Makassar \\ Program Studi DIV Keperawatan \\ Email : budisetyawan1995@gmail.com \\ 085340881945
}

\begin{abstract}
Diabetes Mellitus is a group of metabolic diseases with characteristics of hyperglycemia that occur due to abnormalities of insulin secretion, insulin action or both. Long-term complications including cardiovascular disease (double risk), chronic kidney failure (main cause of dialysis), retinal damage that can cause blindness, and nerve damage that can cause impotence and gangrene with the risk of amputation. The purpose of this study was to find out the level of patient's knowledge of the incidence of complications in diabetes mellitus patients in Pelamonia Hospital Makassar. This study used case control design with Observational Analytic design. Population in this research is patient of Diabetes Melitus in Pelamonia Hospital of Makassar. Sampling method using quota sampling, amounted to 30 respondents with sample distribution of 15 people in the case group and 15 people in the control group. The results were obtained by using ChiSquare statistical test with Odd Ratio or $\operatorname{Exp}(B)=6.000$, with results if the level of knowledge is good it will lead to 6 times no complications of diabetes mellitus, with a $p$-value of 0.025 where $p<\alpha(0.025<0.05)$ then Ha accepted. The conclusion of this study is the influence of the level of knowledge of the incidence of complications of diabetes mellitus in Pelamonia Hospital Makassar.
\end{abstract}

Keywords: Diabetes Mellitus, Knowledge, Complication Events

\section{ABSTRAK}

Diabetes Mellitus adalah suatu kelompok penyakit metabolik dengan karakteristik hiperglikemia yang terjadi karena kelainan sekresi insulin, kerja insulin atau kedua-duanya Komplikasi jangka lama termasuk penyakit kardiovaskular (risiko ganda), kegagalan kronis ginjal (penyebab utama dialisis), kerusakan retina yang dapat menyebabkan kebutaan, serta kerusakan saraf yang dapat menyebabkan impotensi dan gangren dengan risiko amputasi. Tujuan penelitian ini diketahuinya tingkat pengetahuan pasien terhadap kejadian komplikasi pada penderita diabetes mellitus di RS Pelamonia Makassar. Penelitian ini menggunakan rancangan case control dengan desain Analitik Observasional. Populasi dalam penelitian ini adalah pasien Diabetes Melitus di RS Pelamonia Makassar. Metode pengambilan sampel menggunakan quota sampling, berjumlah 30 responden dengan distribusi sampel 15 orang pada kelompok kasus dan 15 orang pada kelompok kontrol. Hasil penelitian diperoleh dengan menggunakan Uji statistik Chi-Square didapatkan nilai Odd Ratio atau $\operatorname{Exp}(B)=6.000$, dengan hasil jika tingkat pengetahuan baik maka akan mengakibatkan 6 kali tidak terjadi komplikasi diabetes mellitus, dengan $p$-Value sebesar 0.025 dimana $p<a(0.025<0.05)$ maka Ha diterima. Kesimpulan penelitian ini terdapat pengaruh tingkat pengetahuan terhadap kejadian komplikasi diabetes melitus di RS Pelamonia Makassar.

\section{Kata Kunci : Diabetes Mellitus, Pengetahuan, Kejadian Komplikasi}

\section{PENDAHULUAN}

Diabetes Mellitus (DM) adalah salah satu penyakit yang berbahaya yang kerap disebut sebagai silent killer selain penyakit jantung, penyakit ini juga merupakan salah satu masalah kesehatan yang besar.

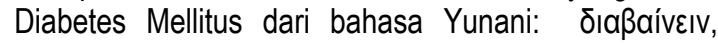
diabaínein, tembus atau pancuran air dan bahasa Latin:
Mellitus, (rasa manis) yang juga dikenal di Indonesia dengan istilah penyakit kencing gula atau kencing manis yaitu kelainan metabolis yang disebabkan oleh banyak faktor, dengan simtoma berupa hiperglisemia kronis dan gangguan metabolisme karbohidrat, lemak dan protein. Komplikasi jangka lama termasuk penyakit kardiovaskular (risiko ganda), kegagalan kronis ginjal 
(penyebab utama dialisis), kerusakan retina yang dapat menyebabkan kebutaan, serta kerusakan saraf yang dapat menyebabkan impotensi dan gangren dengan risiko amputasi (Supriadi S, 2013).

Data dari Studi Global menunjukan bahwa jumlah penderita Diabetes Mellitus pada tahun 2011 telah mencapai 366 juta orang. Jika tidak ada tindakan yang dilakukam, jumlah ini diperkirakan akan meningkat menjadi 552 juta pada tahun 2030. Diabetes Mellitus telah menjadi penyebab dari 4,6 juta kematian.

Lembaga kesehatan dunia, atau World Health Organisation (WHO) mengingatkan prevalensi penderita diabetes di Indonesia berpotensi mengalami kenaikan drastis dari 8,4 juta orang pada tahun 2000 menjadi 21,3 juta penderita di 2030 nanti. Lonjakan penderita itu bisa terjadi jika negara kita tidak serius dalam upaya pencegahan penaganan dan kepatuhan dalam pengobatan penyakit. Pada tahun 2006, terdapat lebih dari 50 juta orang yang menderita DM di Asia Tenggara (Trisnawati, 2013).

Menurut hasil Riskesdas Tahun 2013 Prevalensi diabetes di Sulawesi Selatan yang didiagnosis dokter sebesar 1,6 persen. DM yang didiagnosis dokter atau berdasarkan gejala sebesar 3,4 persen. Berdasarkan data dari Dinas Kesehatan Kota Makassar, angka kejadian penyakit diabetes melitus pada tahun 2011 yaitu 5700 kasus. Pada tahun 2012 angka kejadian kasus DM meningkat menjadi 14.067 kasus, tahun 2013 menjadi 14.604 kasus dan semakin meningkat di tahun 2014 menjadi 21.452 kasus (Dinkes Kota Makassar, 2015).

Angka kejadian penderita DM yang besar berpengaruh peningkatan komplikasi. Menurut Soewondo dkk (2010) dalam Purwanti (2013) sebanyak 1785 penderita diabetes melitus di Indonesia yang mengalami komplikasi neuropati $(63,5 \%)$, retinopati $(42 \%)$, nefropati $(7,3 \%)$, makrovaskuler $(6 \%)$,mikrovaskuler $(6 \%)$, dan kaki diabetik $(15 \%)$. Adapun cara pencegahan komplikasi pada penderita DM yaitu melakukan kontrol kadar gula darah,periksa rutin gula darah, konsumsi obat hipoglikemi, latihan fisik ringan dan patuh dalam diit rendah kalori (Arisman, 2011).

Berdasarkan hasil penelitian yang dilakukan oleh Shara Kurnia Trisnawati tahun 2013 dengan judul faktor risiko kejadian Diabetes Mellitus menunjukkan bahwa faktor risiko umur, stress, dan merokok, dan pengetahuan berhubungan dengan kejadian Diabetes Mellitus (Trisnawati tahun 2013).

Sedangkan menurut hasil penelitian Putri Wulandini S, Roni Saputra dan Hasan Basri (2013) menyatakan bahwa didapatkan pengetahuan penderita
Diabetes Melitus mayoritas tinggi 15 responden $(51,7 \%)$, dengan angka kejadian mayoritas tidak terjadi 20 responden $(69,0 \%)$. Ini menunjukkan ada hubungan antara pengetahuan penderita Diabetes Melitus dengan kejadian luka Diabetes Melitus. Peneliti menyarankan kepada penderita Diabetes Melitus, agar selalu mencari informasi tentang Diabetes Melitus, upaya pencegahan terjadinya luka Diabetes Melitus.

Sementara Iwan Yuwindry, Chairun Wiedyaningsih, dan Gunawan Pamudji Widodo (2016) menyatakan bahwa tingkat pengetahuan pasien diabetes mellitus tipe 2 berpengaruh signifikan terhadap kualitas hidup sebesar $31,6 \%$. Tingkat pengetahuan pasien diabetes mellitus tipe 2 berpengaruh signifikan terhadap kepatuhan penggunaan obat sebesar 25,1\%. Kepatuhan penggunaan obat pasien diabetes mellitus tipe 2 berpengaruh signifikan terhadap kualitas hidup sebesar $75,2 \%$. Kepatuhan penggunaan obat sebagai variabel antara meningkatkan pengaruh tingkat pengetahuan pasien DM tipe 2 terhadap kualitas hidup dari $24 \%$ menjadi $29 \%$.

Penderita Diabetes Mellitus di RS Pelamonia Makassar berdasarkan data dari instalasi Rekam Medik , jumlah penderita Diabetes Mellitus pada tahun 2015 sebanyak 102 orang terdiri dari 42 orang $(41,18 \%)$ lakilaki dan 60 orang $(58,82 \%)$ perempuan, pada tahun 2016 penderita Diabetes Mellitus sebanyak 81 orang, 33 orang $(40,74 \%)$ berjenis kelamin laki-laki dan 48 orang $(59,26 \%)$ berjenis kelamin perempuan, sedangkan tahun 2017 jumlah 71 orang, terdiri dari lakilaki 28 orang $(39,44 \%)$ dan perempuan 43 orang $(60,56 \%)$. (Data Rekam medik RS Pelamonia, 20152017). Berdasarkan data diatas dapat disimpulakn bahwa penderita Diabetes Mellitus di RS Pelamonia Makassar dari tahun 2015 sampai 2017 mengalami penurunan.

Dari uraian dan data tersebut diatas menunjukkan adanya peningkatan jumlah penderita Diabetes Mellitus baik secara global, nasional maupun di daerah khususnya di RS Pelamonia Makassar, oleh karena itu peneliti menganggap pentingnya penelitian tentang tingkat pengetahuan pasien terhadap kejadian komplikasi pada penderita diabetes mellitus di RS Pelamonia Makassar.

\section{METODE}

Jenis penelitian pada penelitian ini adalah analitik dengan desain Analitik Observasional dengan rancangan studi case control yang bertujuan untuk melihat tingkat pengetahuan tehadap kejadian komplikasi diabetes mellitus di RS Pelamonia Makassar. 
Vol. 08. No. 02. 2017.

e-issn : 2622-0148, p-issn : 2087-0035

Penelitian ini dilakukan pada tanggal 05 Juli s.d. 18 Juli 2018 di RS Pelamonia Makassar.

Populasi adalah wilayah generalisasi yang terdiri atas obyek/subyek yang mempunyai kuantitas dan karakteristik tertentu yang ditetapkan oleh peneliti untuk dipelajari dan kemudian ditarik kesimpulannya (Sugiyono, 2010). Populasi dalam penelitian ini adalah pasien dengan Diabetes Mellitus yang berkunjung ke RS Pelamonia Makassar.

Sampel adalah bagian dari jumlah dan karakteristik yang dimiliki oleh populasi (Sugiyono, 2010: 62). Pengambilan sampel dalam penelitian ini dengan teknik non probability sampling yaitu quota sampling. Menurut Hidayat (2017:79), Non Probability Sampling adalah teknik pengambilan sampel dengan tidak memberikan peluang yang sama dari setiap anggota populasi, dengan tujuan tidak untuk generalisasi, yang berasal pada probabilitas yang tidak sama.

Jumlah sampel dalam penelitian ini berjumlah 30 orang dengan pembagian 2 kelompok yaitu 15 orang pada kelompok penderita DM denga komplikasi dan 15 orang lagi pada kelompok penderita DM tanpa komplikasi.

Pengambilan sampel dilakukan dengan teknik quota sampling yaitu cara pengambilan sampel dengan menetukan ciri-ciri tertentu sampai jumlah kuota yang telah ditentukan (Hidayat, 2017).

\section{HASIL}

Tabel 1. Distribusi Frekuensi Responden Berdasarkan Tingkat Pengetahuan di RS Pelamonia Makassar

\begin{tabular}{|c|c|c|c|c|}
\hline $\begin{array}{l}\text { Tingkat } \\
\text { Pengeta } \\
\text { huan }\end{array}$ & f(kasus) & $f$ (kontrol) & Total & $\%$ \\
\hline Kurang & 9 & 3 & 12 & 40 \\
\hline Baik & 6 & 12 & 18 & 60 \\
\hline Total & 15 & 15 & 30 & 100 \\
\hline
\end{tabular}

Berdasarkan tabel 1 dapat diketahui bahwa responden yang memiliki tingkat pengetahuan baik yakni sebanyak 18 orang $(60 \%)$ dengan pembagian 6 orang pada kelompok kasus dan 12 orang pada kelompok kontrol, sedangkan responden yang memiliki tingkat pengetahuan kurang sebanyak 12 orang (40\%) dengan pembagian 9 oraang pada kelompok kasus dan 3 orang pada kelompok kontrol.

Tabel 2. Distribusi Frekuensi Responden Berdasarkan Umur di RS Pelamonia Makassar

\begin{tabular}{ccccc}
\hline Kategori Umur & $\mathrm{f}$ (kasus) & $\mathrm{f}$ (kontrol) & Total & $\%$ \\
\hline 44-51 tahun & 10 & 9 & 19 & 63.3 \\
52-59 tahun & 5 & 6 & 11 & 36.7 \\
Total & 15 & 15 & 30 & 100 \\
\hline
\end{tabular}

Berdasarkan tabel 2 dapat diketahui bahwa penderita Diabetes Melitus di RS Pelamonia Makassar pada usia 44 - 51 tahun yakni berjumlah 19 orang $(63,3 \%)$ dengan pembagian 10 orang pada kelompok kasus dan 9 orang pada kelompok kontrol,sedangkan pada usia 52 - 59 tahun sebanyak 11 orang $(36,7 \%)$ dengan pembagian 5 orang pada kelompok kasus dan 6 orang pada kelompok kontrol.

Tabel 3. Distribusi Frekuensi Responden Berdasarkan Jenis Kelamin di RS Pelamonia Makassar

\begin{tabular}{ccccc}
\hline Jenis Kelamin & $\begin{array}{c}f \\
\text { (kasus) }\end{array}$ & $\begin{array}{c}f \\
\text { (kontrol) }\end{array}$ & Total & $\%$ \\
\hline Laki-Laki & 4 & 4 & 8 & 26.7 \\
Perempuan & 11 & 11 & 22 & 73.3 \\
Total & 15 & 15 & 30 & 100 \\
\hline
\end{tabular}

Berdasarkan tabel 3 dapat diketahui bahwa responden terbanyak yang menderita Diabwetes Melitus di RS Pelamonia Makassar ialah perempuan sebanyak 22 orang $(73,3 \%)$ dengan pembagian 11 orang pada kelompok kasus dan 11 orang pada kelompok kontrol, sedangkan laki-laki sebanyak 8 orang $(26,7 \%)$ dengan pembagian 4 orang pada kelompok kasus dan 4 orang pada kelompok kontrol.

Tabel 4. Distribusi Frekuensi Responden

Berdasarkan Komplikasi Diabetes Melitus di RS Pelamonia Makassar

\begin{tabular}{lcc}
\hline Lama Menderita DM & $\mathrm{F}$ & $\%$ \\
\hline Ada kompikasi & 15 & 50 \\
Tidak ada komplikasi & 15 & 50 \\
Total & 30 & 100 \\
\hline
\end{tabular}

Dari tabel 4 menunjukkan bahwa responden

Diabetes Melitus yang telah ada komplikasinya sebanyak $15(50 \%)$ dan yang tidak memiliki komplikasi juga sebanyak 15 orang (50\%).

Tabel 5. Hasil analisis chi-square tingkat pengetahuan terhadap kejadian komplikasi pada penderita DM di RS Pelamonia Makassar

\begin{tabular}{cccccccccc}
\hline \multirow{2}{*}{$\begin{array}{c}\text { Tingkat } \\
\text { Pengetah } \\
\text { uan }\end{array}$} & \multicolumn{4}{c}{ Komplikasi } & \multicolumn{2}{c}{ Total } & & $\begin{array}{c}\text { OR } \\
\text { (Odds }\end{array}$ \\
\cline { 2 - 5 } Ka & $\mathrm{n}$ & $\%$ & $\mathrm{n}$ & $\%$ & $\mathrm{n}$ & $\%$ & & $\begin{array}{c}\text { Tidak } \\
\text { Ratio) }\end{array}$ \\
\hline Kurang & 9 & 75 & 3 & 25 & 12 & 100 & & 6,025 \\
Baik & 6 & 33, & 12 & 66, & 18 & 100 & & \\
Total & 1 & 5 & 50 & 15 & 50 & 30 & 100 & & \\
\hline
\end{tabular}

Berdasarkan tabel 5 diperoleh hasil bahwa responden yang mengalami komplikasi DM cenderung memiliki tingkat pengetahuan kurang dengan jumlah 9 orang $(75 \%)$. dibandingkan responden yang tidak mengalami komplikasi DM dengan jumlah 3 orang (25\%). Dan responden yang tidak mengalami 
Vol. 08. No. 02. 2017.

e-issn : 2622-0148, p-issn : 2087-0035

komplikasi DM cenderung memiliki tingkat pengetahuan baik dengan jumlah 12 orang $(66,7 \%)$ dibanding responden yang responden yang mengalami komplikasi sebanyak 6 orang $(33,3 \%)$.

Hasil analisis lebih lanjut didapatkan ada pengaruh faktor resiko tingkat pengetahuan terhadap kejadian komplikasi DM dengan nilai $p=0,025<\alpha=0,05$. Juga didapatkan nilai odds ratio $(O R)=6,000$, berdasarkan ketentuan :

a. Jika $O R>1$ bersifat resiko

b. Jika $O R=1$ netral (tidak ada beda)

c. Jika OR $<1$ bersifat protektif

Menunjukkan bahwa pengaruh tingkat pengetahuan terhadap kejadian komplikasi DM dengan nilai 6,000 didapatkan gambaran bahwa kejadian pasien dengan tingkat pengetahuan kurang cenderung enam kali lebih beresiko mengalami komplikasi dibandingkan pasien dengan tingkat pengetahuan baik.

\section{PEMBAHASAN}

Dari tabel 5 diatas diperoleh hasil bahwa responden yang mengalami komplikasi DM cenderung memiliki tingkat pengetahuan kurang dibandingkan responden yang tidak mengalami komplikasi DM.

Dari hal tersebut maka dapat disimpulkan bahwa tingkat pengetahuan berpengaruh terhadap kejadian komplikasi pada penderita DM.

Peneliti berpendapat bahwa kurangnya pengetahuan pasien tentang penyakitnya, menyebabkan pasien tidak dapat mengambil keputusan untuk mengatasi penyakitnya dan mencegah komplikasi lebih lanjut. Sebaliknya pengetahuan yang baik mencegah terjadinya komplikasi pada pasien dikarenakan pasien mengetahui hal-hal apa yang perlu dilakukan dalam rangka pencegahan komplikasi, pendapat tersebut didukung oleh beberapa hasil penelitian. Penelitian yang dilakukan oleh Baharuddin, Hasmawaty (2016) didapatkan hasil bahwa pengetahuan yang kurang memiliki kecenderungan terjadi komplikasi.

Sedangkan pada penelitian yang dilakukan oleh Hasmirati (2013) pada penelitiannya hubungan anatara penatalaksanaan manajemen diabetes mellitus dengan resiko terjadinya komplikasi didapatkan hasil bahwa semakin tinggi tingkat pengetahuan pasien tentang diabetes mellitus maka resiko terjadinya komplikasi lebih kecil begitu pula sebaliknya.

Adapun pada pada penelitian yang dilakukan oleh Riza Triana, Darwin Karim, Jumaini (2014) yang menyatakan bahwa terdapat hubungan tingkat pengetahuan pasien diabetes mellitus tentang penyakit dan diet dengan kepatuhan dalam menjalankan diet diabetes mellitus dan juga diantara hasil yang disimpulkan bahwa responden dengan tingkat pengetahuan tinggi memiliki peluang untuk tujuh kali lebih patuh dalam menjalankan diet DM dibandingkan responden yang memiliki tingkat pengetahuan rendah. Hal ini menunjukkan bahwa pengetahuan yang baik tidak serta-merta dapat mencegah terjadinya komplikasi diabetes mellitus, namun harus disertai dengan kepatuhan dan kedisiplinan pasien dalam diet yang dijalani.

Pengetahuan penderita tentang Diabetes Melitus merupakan sarana yang dapat membantu penderita menjalankan penanganan Diabetes Melitus selama hidupnya sehingga semakin banyak semakin baik penderita mengerti bagaimana harus mengubah perilakunya dan mengapa hal itu diperlukan (Waspadji, 2015).

Pengetahuan yang baik diperoleh dari proses pembelajaran yang baik, dengan demikian penyebab penderita Diabetes Melitus yang memiliki pengetahuan yang masih kurang salah satunya yaitu kurangnya informasi yang bisa diterima saat mendapatkan informasi kesehatan. Hal ini sesuai dengan pendapat Notoadmojdo dalam penelitian Lubis (2012) bahwa pengetahuan merupakan hasil dari tahu dan ini terjadi setelah orang melakuan penginderaan terhadap suatu objek tertentu seperti mengikuti pendidikan kesehatan. Pengetahuan merupakan domain yang sangat penting untuk terbentuknya sikap dan tindakan seseorang.

Peneliti berasumsi bahwa kurangnya pengetahuan penderita Diabetes Melitus di RS Pelamonia Makassar karena kurangnya keterpaparan informasi mengenai Diabetes Melitus, serta usia juga dapat mempengaruhi tindakan penderita Diabetes Melitus dalam pengaturan pola makan. Hal ini dikarenakan bertambahnya usia seseorang dapat berpengaruh pada pertambahan pengetahuan yang diperoleh, dan pada usia-usia tertentu atau menjelang usia lanjut kemampuan penerimaan atau mengingat suatu pengetahuan akan berkurang. Sehingga dari pengetahuannya yang kurang tersebut dapat meningkatkan resiko terjadinya komplikasi diabetes mellitus.

\section{KESIMPULAN}

Berdasarkan uraian yang telah dijelaskan dapat disimpulkan sebagai berikut :

Secara umum, didapatkan kesimpulan bahwa adanya pengaruh tingkat pengetahuan terhadap kejadian komplikasi Diabetes Melltus di RS Pelamonia Makassar. Didapatkan pada kelompok penderita DM dengan komplikasi lebih banyak penderita yang memiliki tingkat pengetahuan kurang dan pada kelompok penderita DM tanpa komplikasi didapatkan 
lebih banyak penderita yang memiliki tingakat pengetahuan baik. Sehingga, dari hal tersebut menunjukkan bahwa jika tingkat pengetahuan penderita DM kurang maka akan beresiko enam kali lebih tinggi mengalami komplikasi dibandingkan jika tingkat pengetahuan baik.

\section{SARAN}

Penderita Diabetes Melitus dan keluarga agar lebih memperkaya informasi mengenai diabetes mellitus dan komplikasi yang akan terjadi jika tidak dikendalikan, serta memulai dengan keteraturan menjalankan program yang telah dianjurkan oleh tenaga kesehatan.

Perlu adanya edukasi/ penyuluhan mengenai Dabetes Melitus kepada penderita baik secara berkelompok ataupun perorangan 2-3 kali dalam sebulan untuk penderita Diabetes Melitus dan keluarganya.

Adanya pengembangan pemberian informasi tentang Diabetes Melitus, seperti pemasangan baliho/spanduk di lingkungan Rumah Sakit.

Diharapkan peneliti selanjutnya meneliti beberapa variabel pengganggu yang tidak dikendalikan pada penelitian ini seperti faktor sosial, ekonomi, serta budaya dan lingkungan.

\section{DAFTAR PUSTAKA}

Andra Safera Wijaya dan Yessi Mariza P, 2013. Keperawatan Medikal Bedah. Nuha Medika. Yogyakarta.

Anggraeni,D.M \& Saryono. (2013). Metodelogi Penelitian Kualitatif dan Kuantitatif dalam Bidang Kesehatan. Yogyakarta: Nuha Medika.

Arisman. (2011). Obesitas, Diabetes Melitus \& Dislipidemia. Jakarta: Penerbit Buku Kedokteran EGC

Baharuddin dan Hasmawaty. 2016. Hubungan Antara Status Ekonomi dan Pengetahuan Dengan Kejadian Komplikasi Pada Pasien Diabetes Mellitus Yang Dirawat Inap Di RSu Lasinrang. DIII Keperawatan.

Corwin, Elizabeth J, 2009, Buku Saku Patofisiologi, EGC, Jakarta.

Dinas Kesehatan Kota Makassar. 2015. Prevalensi penderita Diabetes Mellitus.

Hasmirati. 2013. Hubungan Penatalaksanaan Manajemen Diabetes Mellitus Tipe II dengan Resiko Terjadinya Komplikasi Pada Pasien DI Wilayah Kerja Puskesmas Suppa kabupaten Pinrang. Poltekkes Makassar.

Hidayat, A. Aziz Alimul, 2017. Metode Penelitian Keperawatan dan Tehnik Analisa Data. Salemba medika, Jakarta.

Lubis. 2012. Dukungan Sosial Pada Pasien Gagal Ginjal Terminal Yang Melakukan Terapi Hemodialisa. Makalah. USU Repository ; 24-7.

Marewa Lukman Haris. 2015. Kencing Manis (Diabtes Melitus) di Sulawesi Selatan. Jakarta: Yayasan Pustaka Obor Indonesia.

Notoatmodjo, Soekidjo. 2005. Metodologi penelitian kesehatan, Asdi Mahasatya, Jakarta.

Notoatmodjo,S. (2005). Metodologi Penelitian Kesehatan. Jakarta : RinekaCipta

Notoatmojo, S. Promosi Kesehatan dan IImu Perilaku. Jakarta : Rineka Cipta. 2007

Notoatmodjo, Soekidjo. 2010. Metodologi penelitian kesehatan, Asdi Mahasatya, Jakarta.

Nursalam, 2008, Konsep \& Penerapan Metodologi Penelitian IImu Keperawatan. Salemba Medika. Jakarta.

Purnamasari, D. 2009. Diagnosis dan Klasifikasi Diabetes Melitus : Buku Ajar IImu Penyakit Dalam Jilid III Edisi V. Jakarta. Balai Penerbit Fakultas Kedokteran Universitas Indonesia.. $1134 \mathrm{hlm}$. 
Purwanti, O. S. (2013). Analisis Faktor-Faktor Resiko Terjadinya Ulkus Kaki pada Pasien Diabetes Melitus di RSUD Moewardi Surakarta. Tesis: Universitas Indonesia .

Rekam Medik Rumah Sakit Pelamonia Makassar Tahun 2015-2017.

Rikesdas. 2013. riset kesehatan dasar. Jakarta : badan penelitian dan pengembangan kesehatan : http://www.depkes.go.id/resources/download/general/hasil\%20rikesdas\%20 201.Pdf. diakses 01 Agustus 2018.

Soewondo, P., Soegondo, S., Sustika, K., Pranoto, A., Soeatmaji, D. W., Tjokroprawiro, A. (2010). The DiabCare Asia 2008 study - Outcomes on control and Complications of Type 2 Diabetic Patients in Indonesia, Med J Indonesia.

Sugiyono, 2010. Metode Penelitian Kuantitatif, Kualitatif, Dan R\&D, Alfabeta, Bandung.

Supriadi Supri, 2013 Asuhan Keperawatan Pada Klien dengan DM, (online), (http://nerskece.co diakses Februari 2018)

Triana, Riza, dkk. 2014. Hubungan Tingkat Pengetahuan Pasien Diabetes Mellitus Tentang Penyakit Dan Diet Dengan Kepatuhan Dalam Menjalankan Diet Diabetes Mellitus. Universitas Riau. Riau

Trisnawati, Shara K, dkk. 2013. Faktor Risiko Kejadian Diabetes Melitus Tipe II di Puskesmas Kecamatan Cengkareng Jakarta Barat Tahun 2012. Jurnal IImiah Kesehatan, Vol.5 No.1:1-11.

Waspadji, S. 2015. Buku Ajar IImu Penyakit Dalam. Jakarta: Departemen IImu Penyakit Dalam Fakultas Kedokteran Universitas Indonesia.

Wulandini S, Putri, dkk. 2013. Hubungan Pengetahuan Penderita Diabetes Melitus Terhadap Kejadian Luka Diabetes Melitus Di Ruangan Penyakit Dalam Rsud Arifin Achmad Pekanbaru. Universitas Abdurrab. Pekanbaru. Diakses dari : http://jurnal.univrab.ac.id/index.php/keperawatan/article/download/72/47

Yuwindry I, dkk. 2012. Pengaruh Pengetahuan Terhadap Kualitas Hidup Dengan Kepatuhan Penggunaan Obat Sebagai Variabel Antara Pada Pasien DM. Universitas Gajah Mada. Diakses dari : https://journal.ugm.ac.id/jmpf/article/download/29413/pdf 